\title{
A Comprehensive Review of Sugarcane
}

Hayat Ullah ${ }^{1 *}$, Asad Ullah ${ }^{2}$, Muhammad Lateef $^{3}$ and Muhammad Waseem Khan ${ }^{4}$

${ }^{1}$ Department of Bioinformatics \& Biotechnology, Faculty of Life Science, Government College University Faisalabad-Pakistan.

${ }^{2}$ Department of Microbiology, Faculty of Life Science and Informatics, Balochistan University of Information Technology Engineering and Management Sciences, Quetta, Pakistan.

${ }^{3}$ Biotechnology Department of Center for Agricultural Biochemistry \& Biotechnology Faculty of Agriculture, University of Agriculture, Faisalabad-Pakistan

${ }^{4}$ Department of Biotechnology, Faculty of Life Sciences and Informatics, Balochistan University of Information Technology Engineering and Management Sciences, Quetta, Pakistan.

\section{Corresponding author: *}

\section{Hayat Ullah}

Department of Bioinformatics \& Biotechnology, Faculty of Life Science, Government College University Faisalabad-Pakistan, 38000

E-mail: hayatullah22@gcuf.edu.pk

Phone: +92-315-5655677

\begin{abstract}
Sugarcane is an important industrial crop of semitropical and tropical areas. Due to the importance of this crop it is cultivated on nearly 20 million hectares by more than 90 countries. This crop belongs to family Poaceae, a grass family which is economically vital tracheophyte family that has properties much like that of wheat, maize, rice and sorghum. The Poaceae family is globally vital for providing dietary macromolecules, carbohydrates, and different nutrients. The most important item of sugarcane for the consumption is sucrose that gets accumulated in the stalk internodes. Sucrose is taken out and refined by different mills which is used as a sweetener in human food industries and in the fermentation industry. Large production of alcohol is attained by Brazilian sugarcane industries.
\end{abstract}

Keywords: Sugarcane, Cultivation, Housekeeping Genes, 


\section{Introduction}

The capability of sugarcane to accumulate high level of sucrose and vegetative propagation ability make it most important crop among others (Welbaum and Meinzer, 1990; Dillon et al., 2007). World generation of this crop in 2011 brought about around two billion tons of crude material, which related to a gross pay of more than US\$ 52 billion (Tilman et al., 2011). Despite the importance of this crop there are still lots of challenges related to genetic mechanism due to most difficult genome, with diploid numbers ranging from 100 to 130 chromosomes, showing a high ploidy level, and also consistent aneuploidy events (Jannoo et al., 2007). Owing to this complexness, the use of molecular tools represents a gorgeous approach to the development of sugarcane breeding programs.

The high concentration capacity of sucrose in sugarcane makes it most valuable crop among the tropical and subtropical sides. It is necessary to identify the genes that are responsible for control and sucrose accumulation in sugarcane would provide attractive tools for increasing the concentration of sugar by either using genetic modification and selection strategies (Iskandar $e t$ $a l ., 2004)$. Recently, by the analysis of expressed sequence tags (ESTs) several expressed genes have been detected in different tissues of sugarcane (Vettore et al., 2001). Through the macro or microarrays technique a number of gene expressions can be analyzed (Meotti et al., 2003) and by use of these strategies the expressed genes in the mature and immature stems and tissues of the sugarcane have been identified (Iskandar et al., 2004).

\section{Sugarcane cultivation}

Sugarcane producing countries of the world lie between $36{ }^{0} \mathrm{~N}$ and $31^{0} \mathrm{~S}$ of the equator reaches out from tropical to semitropical zone. Worldwide in 107 nations, sugarcane possesses territory of 20.42 million ha with an aggregate production of 1333 million tons (Natrajin, 2005). Sugarcane territory and profitability vary broadly from country to country. Brazil has most astounding zone (5.34 million hectare) while Australia has most elevated profitability ( $85.1 \mathrm{t}$ ha-1). The biggest makers are Brazil, India, China and Pakistan accounting over half of world creation (Qureshi and Afghan, 2005).

World largest producer of sugarcane is Brazil with around 4.5 million hectares planted in northeastern and southeastern region of the country (Galvao et al., 2005). In Brazil, sugarcane is involved to get sugar, anhydrous alcohol (gasoline additive) and hydrous alcohol (natural, clean and renewable pure fuel for vehicles) for the inner external markets (de Oliveira, 2002). To 
enhance the productivity of the Brazilian business, new verities of sugarcane with higher yields are persistently created and tried. A perfect sugarcane verity should adopt environmental variation like climate, soil type and cutting season (Badaloo et al., 1999; Bissessur et al., 2000). It also should have immune to pest, disease and draught conditions having high concentration of sucrose in their tissues (Croft et al., 2000). According to 2018 data the top ten sugarcane producing countries are following.

Table 1.1 Top ten Sugarcane Producing Countries.

\begin{tabular}{|l|l|l|}
\hline S.No & Countries & Production \\
\hline 1 & Brazil & 739.3 million metric tons \\
\hline 2 & India & 341.2 million metric tons \\
\hline 3 & China & 125.5 million metric tones \\
\hline 4 & Thailand & 100.1 million metric tons \\
\hline 5 & Pakistan & 63.8 million metric tons \\
\hline 6 & Mexico & 61.2 million metric tons \\
\hline 7 & Columbia & 34.9 million metric tons \\
\hline 8 & Indonesia & 33.7 million metric tons \\
\hline 9 & Philippines & 31.9 million metric tons \\
\hline 10 & United States & 29.235 million metric tons \\
\hline
\end{tabular}

\section{Sugarcane production in Pakistan}

Sugarcane is the second biggest money yield of Pakistan and is being developed on 0.966 million hectares contributing around 3.6\% of Gross local creation (GDP) (Qureshi and Afghan, 2005). At present records it accounts for $4.8 \%$ cropped area and $11 \%$ value added of the aggregate products (Zia-ul-Hussnaln et al.). The sugar industries play important part for the development of Pakistani economy. This crop is not only source of sucrose but also provides fiber, biofuel, compost and other organic fertilizer with ecologically viable properties. Molasses is the least expensive sustain stock for the refineries. The bagasse has been acknowledged as a reasonable elective crude material to wood in the paper and mash industry. The industry of sugar almost contributes 4 billion rupees to the Govt directly or indirectly in the form of sale tax (Qureshi and 
Afghan, 2005).

A huge loss of plant yield happened environmental biotic and abiotic stresses during the planting season under various agrarian creation time, which may bring about $70 \%$ lessening of the potential yields of harvest plants (Agarwal et al., 2006). Abiotic stresses coming just because of water shortage, high saltiness, or times of dry season unfavorably influence plant development and shows major driving force for plant evolution (Inze and MONTAGU). These stresses constitute genuine dangers to farming due to the failure to control water accessibility aside from through exorbitant water system methodologies. Universally, an information from FAO in 2004 demonstrated that around $22 \%$ of the agrarian area is salty, and the inexorably harm caused by shortage of water has been accounted to constrain plant development which results loss of efficiency of plants particularly in crop species (Burke et al., 2006).

\section{Sugarcane modification}

Traditional strategy like breeding is not so effective for the resistance improvement due to the lack of information related to stress tolerance trait. Therefore, world demand cannot be full fill because of lack of information related to stress, absence of effective choice method and low of genetic variance and fertility (Rodríguez et al., 2005). Recently, few technuques known as hybridization (Patade et al., 2011), cDNA-microarray (Casu et al., 2004), transcriptome (Manners and Casu, 2011), transcript expression (Patade et al., 2012), proteome (Zhou et al., 2012) and microRNAseq (Gentile et al., 2013) are the effective tools to determine the genes and molecular markers which are related to the environmental responses, and also the modification of these genes and markers would have a vast benefit for the improvement of breeding, that gave much better results (Sreenivasulu et al., 2007).

Transcriptomic studies are prioritized, permitting identification of candidate genes concerned in biological process and plant responses to environmental cues that have eventually led to the invention of practical molecular markers (Manners and Casu, 2011). Quantitative real time reverse transcription PCR depend on high particular polymerase chain reaction related with delicate fluorescence, permitting the identification of variation in gene expression, together with discreetly transcribed genes (Guénin et al., 2009). This technology has been used as a diagnostic tool for identification of plant pathogen, external transgene expression (Gachon et al., 2004), human diseases (Gao et al., 2013) and confirmation of transcriptional profiles generated by totally different methodologies, like Eastern Time libraries (Yong et al., 2011), microarray (Golisz et al., 
2011), HT-SuperSAGE (Molina et al., 2011) and RNA-seq (Bleeker et al., 2011).

Now a days, an analytical technique known as quantitative PCR (qPCR) also referred as real time PCR widely used for gene expression analyses. The main advantages of the real time PCR as compare to the conventional reverse transcription-polymerase chain reaction (RT-PCR) are its high specifity, sensitivity and broad quantification range up to several order magnitude (Bustin, 2002; Gachon et al., 2004). In spite of being very high technique for exactly measuring changes in gene expression, some factors like RNA quality and integrity, potency of DNA synthesis and variation in RNA effect the performance on $\mathrm{qPCR}$ performance and will not get good results (Bustin, 2002; Granados et al., 2016).

To stay away from the impact of these components, a standardization gene expression data is needed (Pfaffl et al., 2004) to correct variations that exist among the samples and conditions (Jain et al., 2006; Paolacci et al., 2009). To select an appropriate reference gene for qPCR analyses there are different mathematical algorithms are planned, like NormFinder, GeNorm, and DeltaCT (Silver et al., 2006). RefFinder is another algorithmic program used for reference sequences analyses, grouping all pervious algorithms cited for the higher assessing a comprehensive ranking of stability genes (Xie et al., 2012). Therefore, identification of an appropriate reference sequence extremely and perpetually expressed is vital so as to get reliable results (Dean et al., 2002).

During the RT-qPCR, product formation is observed throughout every cycle of the reaction (Saunders, 2004) to get fast and specific detection of the amplified product (Gachon et al., 2004). Expression of the target sequence is typically normalized relative to the reference sequence that is either illustrious or assumed to specific stable levels of transcript in most tissue or a minimum of within the tissue being compared. One or many reference genes are the basic demand of getting reliable results of gene expression by qRT-PCR. These sequences show uniform expression across various experimental samples and serve as the interior control which is basic approach to balance the difference between the reaction and samples (Nicot et al., 2005; Ovesna et al., 2012).

\section{Sugarcane housekeeping genes}

Housekeeping genes are basically needed for basal activities of the cells. There are number of genes such as glyceraldehyde-3-phosphate (GAPDH), a and b tubulin (TUB), b and c actin (ACT), ubiquitin $(U B Q)$ and $25 S$ ribosomal RNA (25S rRNA) were historically used as a reference gene in bioscience (Thellin et al., 1999) and later in plant sciences (Gutierrez et al., 2008). As result these genes were believed to possess the same level of expression under different treatments, 
tissues and biological process. Other genes like $18 S$ ribosomal RNA (18S rRNA), elongation factor 1-alpha (EF-la), elongation initiation factor 4-alpha (eIF- 4a), cullin (CUL) clathrin device advanced (CAC), tonoplastic intrinsic macromolecule (TIPS-41), anthranilate phosphoribosyl enzyme (APRT) and pseudo response regulator (PRR), that is additionally stably expressed in cultivated rice (Jain et al., 2006), Indian corn (Manoli et al., 2012) and mustard (Chandna et al., 2012) or had been evaluate in sugarcane (Iskandar et al., 2004; Ling et al., 2014).

The term housekeeping gene was earlier often used to define a gene that was anticipated to be essential and stably expressed in the cell and, thus, generally accepted for normalization without the need for experimental evidence for its stability. This is in contrast to the term reference gene, which should be reserved for genes that are experimentally found to be stably expressed in given species and tissues under given experimental conditions and, thus, suitable for quantitative analysis under the respective condition (Løvdal and Lillo, 2009). The prerequisite of a suitable housekeeping gene is that it should, of course, be adequately expressed in the tissue of interest, but most importantly, that it shows minimal variability in expression between samples and under the experimental conditions used (Dheda et al., 2004).

Housekeeping genes are involved in basic cell maintenance and, therefore, are expected to maintain constant expression levels in all cells and conditions. Housekeeping genes are genes that are required for the maintenance of basal cellular functions that are essential for the existence of a cell, regardless of its specific role in the tissue or organism. For example, housekeeping genes were shown to have shorter introns and exons a different repetitive sequence environment [enriched in short interspersed elements (SINEs) and depleted in long interspersed elements (LINEs)], more simple sequence repeats in the 50 un-translated regions (UTR), lower conservation of the promoter sequence, and lower potential for nucleosome formation in the 50 region of these genes. Protein products of housekeeping genes are enriched in some domain families. These studies shed light on general aspects of gene structure and evolution (Goodkind and Edwards, 2005; Eisenberg and Levanon, 2013).

A reference gene always expressed regularly with minimal change in their expressions and has no experimental effect on them (Dean et al., 2002). In some studies the activities of these genes showed that, it can go through stability changes in different abiotic stress conditions (Nicot et al., 2005).Study showed, GAPDH,eukaryotic elongation factor alpha1 and eukaryotic elongation factor alpha4 showed the most stable activity in multiple genotypes coressponding to the different 
abiotic and hormonal stress stmuli (Ling et al., 2014). Guo conducted expriment on sugarcane genes and concluded that GAPDH and eukaryotic elongation factor alpha1 shows the best expression when the genes are treated with $\mathrm{NaCl}$ and PEG800 (Guo et al., 2014). Various reference genes have been studied which are involving in roots and leaves. Among them GAPDH and UBQI are most appropriate genes in different drought conditions (Andrade et al., 2017). Multiple reference gene have been identified, among them (tublin-actin and poly -ubiquitin) were being used for the analyses and normalization of genes activities in sugarcane (Ling et al., 2014).

\section{Acknowledgments}

No acknowledgments

\section{Conflict of Interest}

The authors declare that they have no conflict of interest.

\section{References}

1. Agarwal, P.K., P. Agarwal, M. Reddy and S.K. Sopory, 2006. Role of dreb transcription factors in abiotic and biotic stress tolerance in plants. Plant Cell Rep. 25: 1263-1274.

2. Andrade, L.M., M. Brito, R.P. Junior, P.E.R. Marchiori, P.M. Nóbile, A.P.B. Martins, R.V. Ribeiro and S. Creste, 2017. Reference genes for normalization of qper assays in sugarcane plants under water deficit. Plant Meth. 13: 28-55.

3. Bissessur, D., R. Tilney-Bassett, L.L.S. Chong, R. Domaingue and M. Julien. 2000. Familyx environment and genotypex environment interactions for sugarcane across two contrasting marginal environments in Mauritius. Experimental Agriculture, 36: 101-114.

4. Burke, E.J., S.J. Brown and N. Christidis. 2006. Modeling the recent evolution of global drought and projections for the twenty-first century with the Hadley Centre climate model. Journal of Hydrometeorology, 7: 1113-1125.

5. Casu, R.E., C.M. Dimmock, S.C. Chapman, C.P. Grof, C.L. McIntyre, G.D. Bonnett and J.M. Manners. 2004. Identification of differentially expressed transcripts from maturing stem of sugarcane by in silico analysis of stem expressed sequence tags and gene expression profiling. Plant molecular biology, 54: 503-517.

6. Casu, R.E., C.P. Grof, A.L. Rae, C.L. McIntyre, C.M. Dimmock and J.M. Manners. 2003. Identification of a novel sugar transporter homologue strongly expressed in maturing stem vascular tissues of sugarcane by expressed sequence tag and microarray analysis. Plant molecular biology, 52: 371-386. 
7. Croft, B., R. Magarey and P. Whittle. 2000. Disease management. Manual of canegrowing. Bureau of Sugar Experiment Stations, Brisbane: 263-289.

8. de Oliveira, J.P. 2002. The policymaking process for creating competitive assets for the use of biomass energy: the Brazilian alcohol programme. Renewable and Sustainable Energy Reviews, 6: 129-140.

9. Dean, J., P. Goodwin and T. Hsiang. 2002. Comparison of relative RT-PCR and northern blot analyses to measure expression of $\beta$-1, 3-glucanase inNicotiana benthamiana infected withColltotrichum destructivum. Plant Molecular Biology Reporter, 20: 347-356.

10. Dheda, K., J.F. Huggett, S.A. Bustin, M.A. Johnson, G. Rook and A. Zumla. 2004. Validation of housekeeping genes for normalizing RNA expression in real-time PCR. Biotechniques, 37: 112-119.

11. Dillon, S.L., F.M. Shapter, R.J. Henry, G. Cordeiro, L. Izquierdo and L.S. Lee. 2007. Domestication to Crop Improvement: Genetic Resources for Sorghum and S accharum (Andropogoneae). Annals of botany, 100: 975-989.

12. Eisenberg, E. and E.Y. Levanon. 2013. Human housekeeping genes, revisited. Trends in Genetics, 29: 569-574.

13. Gachon, C., A. Mingam and B. Charrier, 2004. Real-time pcr: What relevance to plant studies? Journal of experimental botany, 55(402): 1445-1454.

14. Galvao, L.S., A.R. Formaggio and D.A. Tisot. 2005. Discrimination of sugarcane varieties in Southeastern Brazil with EO-1 Hyperion data. Remote Sensing of Environment, 94: 523534.

15. Gao, G., R.D. Chernock, H.A. Gay, W.L. Thorstad, T.R. Zhang, H. Wang, X.J. Ma, Y. Luo, J.S. Lewis and X. Wang. 2013. A novel RT-PCR method for quantification of human papillomavirus transcripts in archived tissues and its application in oropharyngeal cancer prognosis. International journal of cancer, 132: 882-890.

16. Gentile, A., T.H. Ferreira, R.S. Mattos, L.I. Dias, A.A. Hoshino, M.S. Carneiro, G.M. Souza, T. Calsa, R.M. Nogueira and L. Endres. 2013. Effects of drought on the microtranscriptome of field-grown sugarcane plants. Planta, 237: 783-798.

17. Golisz, A., M. Sugano, S. Hiradate and Y. Fujii. 2011. Microarray analysis of Arabidopsis plants in response to allelochemical L-DOPA. Planta, 233: 231-240.

18. Goodkind, J.R. and J.S. Edwards. 2005. Gene expression measurement technologies: 
innovations and ethical considerations. Computers \& chemical engineering, 29: 589-596.

19. Guénin, S., M. Mauriat, J. Pelloux, O. Van Wuytswinkel, C. Bellini and L. Gutierrez. 2009. Normalization of qRT-PCR data: the necessity of adopting a systematic, experimental conditions-specific, validation of references. Journal of experimental botany, 60: 487-493.

20. Iskandar, H.M., R.S. Simpson, R.E. Casu, G.D. Bonnett, D.J. Maclean and J.M. Manners, 2004. Comparison of reference genes for quantitative real-time polymerase chain reaction analysis of gene expression in sugarcane. Plant Molecular Biology Reporter, 22(4): 325337.

21. Jain, M., A. Nijhawan, A.K. Tyagi and J.P. Khurana. 2006. Validation of housekeeping genes as internal control for studying gene expression in rice by quantitative real-time PCR. Biochemical and biophysical research communications, 345: 646-651.

22. Jannoo, N., L. Grivet, N. Chantret, O. Garsmeur, J.C. Glaszmann, P. Arruda and A. D'Hont. 2007. Orthologous comparison in a gene-rich region among grasses reveals stability in the sugarcane polyploid genome. The Plant Journal, 50: 574-585.

23. Ling, H., Q. Wu, J. Guo, L. Xu and Y. Que. 2014. Comprehensive selection of reference genes for gene expression normalization in sugarcane by real time quantitative RT-PCR. PloS one, 9: e97469.

24. Løvdal, T. and C. Lillo. 2009. Reference gene selection for quantitative real-time PCR normalization in tomato subjected to nitrogen, cold, and light stress. Analytical biochemistry, 387: 238-242.

25. Manners. 2004. Identification of differentially expressed transcripts from maturing stem of sugarcane by in silico analysis of stem expressed sequence tags and gene expression profiling. Plant molecular biology, 54: 503-517.

26. Meotti, F., V. Borges, G. Zeni, J. Rocha and C. Nogueira. 2003. Potential renal and hepatic toxicity of diphenyl diselenide, diphenyl ditelluride and Ebselen for rats and mice. Toxicology Letters, 143: 9-16.

27. Molina, C., M. Zaman-Allah, F. Khan, N. Fatnassi, R. Horres, B. Rotter, D. Steinhauer, L. Amenc, J.-J. Drevon and P. Winter. 2011. The salt-responsive transcriptome of chickpea roots and nodules via deepSuperSAGE. BMC plant biology, 11: 31.

28. Natrajin, B. 2005. Sugar and sugarcane international and national scenario and the role of sugarcane breeding institute in varietal improvement in India. Int. Trg. Oct, 10. 
29. Nicot, N., J.-F. Hausman, L. Hoffmann and D. Evers. 2005. Housekeeping gene selection for real-time RT-PCR normalization in potato during biotic and abiotic stress. Journal of experimental botany, 56: 2907-2914.

30. Ovesna, J., L. Kučera, K. Vaculová, K. Štrymplová, I. Svobodova and L. Milella. 2012. Validation of the $\beta$-amy 1 transcription profiling assay and selection of reference genes suited for a RT-qPCR assay in developing barley caryopsis. PloS one, 7: e41886.

31. Paolacci, A.R., O.A. Tanzarella, E. Porceddu and M. Ciaffi. 2009. Identification and validation of reference genes for quantitative RT-PCR normalization in wheat. BMC molecular biology, 10: 11.

32. Patade, V.Y., A.N. Rai and P. Suprasanna. 2011. Expression analysis of sugarcane shaggylike kinase (SuSK) gene identified through cDNA subtractive hybridization in sugarcane (Saccharum officinarum L.). Protoplasma, 248: 613-621.

33. Patade, V.Y., S. Bhargava and P. Suprasanna. 2012. Transcript expression profiling of stress responsive genes in response to short-term salt or PEG stress in sugarcane leaves. Molecular biology reports, 39: 3311-3318.

34. Qureshi, M.A. and S. Afghan. 2005. Sugarcane cultivation in Pakistan. Sugar Book Pub. Pakistan Society of Sugar Technologist.

35. Rodríguez, M., E. Canales and O. Borrás-Hidalgo. 2005. Molecular aspects of abiotic stress in plants. Biotecnología Aplicada, 22: 1-10.

36. Silver, N., S. Best, J. Jiang and S.L. Thein. 2006. Selection of housekeeping genes for gene expression studies in human reticulocytes using real-time PCR. BMC molecular biology, 7: 33.

37. Sreenivasulu, N., S. Sopory and P.K. Kishor. 2007. Deciphering the regulatory mechanisms of abiotic stress tolerance in plants by genomic approaches. Gene, 388: 1-13.

38. Thellin, O., W. Zorzi, B. Lakaye, B. De Borman, B. Coumans, G. Hennen, T. Grisar, A. Igout and E. Heinen. 1999. Housekeeping genes as internal standards: use and limits. Journal of biotechnology, 75: 291-295.

39. Tilman, D., C. Balzer, J. Hill and B.L. Befort. 2011. Global food demand and the sustainable intensification of agriculture. Proceedings of the National Academy of Sciences, 108: 20260-20264.

40. Vettore, A.L., F.R.d. Silva, E.L. Kemper and P. Arruda. 2001. The libraries that made 
SUCEST. Genetics and Molecular Biology, 24: 1-7.

41. Welbaum, G.E. and F.C. Meinzer. 1990. Compartmentation of solutes and water in developing sugarcane stalk tissue. Plant Physiology, 93: 1147-1153.

42. Yong, S., C.Y. Choong, P. Cheong, S. Pang, R.N. Amalina, J. Harikrishna, M. Mat-Isa, P. Hedley, L. Milne and R. Vaillancourt. 2011. Analysis of ESTs generated from inner bark tissue of an Acacia auriculiformis x Acacia mangium hybrid. Tree Genetics \& Genomes, 7: 143-152.

43. Zhou, G., L.-T. Yang, Y.-R. Li, C.-L. Zou, L.-P. Huang, L.-H. Qiu, X. Huang and M.K. Srivastava. 2012. Proteomic analysis of osmotic stress-responsive proteins in sugarcane leaves. Plant molecular biology reporter, 30: 349-359.

44. Zia-ul-Hussnaln, S.A., K. Hussein and A. Naheed. SUGARCANE \& ITS PROBLEMS.

45. Zou, J.-W., M. Sun and H.-Y. Yang. 2002. Single-embryo RT-PCR assay to study gene expression dynamics during embryogenesis inArabidopsis thaliana. Plant molecular biology reporter, 20: 19-26. 